\title{
Investigation of the Achaemenid period pottery production technology from the Seyitömer Mound (Kütahya, Turkey)
}

\author{
A. İssi ${ }^{1}$, C. Serkaya ${ }^{1}$, V. Uz ${ }^{1} \&$ A. N. Bilgen ${ }^{2}$ \\ ${ }^{1}$ Department of Materials Science and Engineering, \\ Dumlupinar University, Turkey \\ ${ }^{2}$ Department of Archaeology, Dumlupinar University, Turkey
}

\begin{abstract}
There are many archaeological excavations still being performed in Anatolia to unearth the cultural heritages from the past civilizations. Archaeological excavations started in the Seyitömer Mound in 1989. It is located on a large coal reserve and archaeological excavations need to be completed as soon as possible to utilize the mine. Pottery sherds investigated in this study were unearthed in the Seyitömer Mound and they belong to the Achaemenid period. Characterization studies on findings may contribute to archaeological knowledge about how they produced artifacts. To study the production technology of the Achaemenid pottery sherds, chemical analysis of samples was performed by wavelength dispersive X-ray fluorescence (WDXRF) and mineralogical/phase composition analysis was performed by X-ray diffraction (XRD). Scanning electron microscopy (SEM) and microanalysis technique (EDX) were performed for microstructural and microchemical analysis. Thermogravimetric-differential thermal analysis (TGDTA) were employed to characterize the potsherds. It may be concluded from the results that ceramic bodies have been produced from illitic clays rich in iron and magnesium, containing carbonated minerals such as calcite and dolomite. Finally, considering the obtained results, firing temperatures of the potsherds could be between $600^{\circ} \mathrm{C}$ and $900^{\circ} \mathrm{C}$.

Keywords: Seyitömer Mound, Achaemenid period, ceramic artifact, characterization, archaeometry.
\end{abstract}




\section{Introduction}

There are several ancient sites belonging to many civilizations lived in Anatolia in different periods of history. Archaeological excavations are still being carried out to unearth the cultural heritage of the past civilizations. One of them is the Seyitömer Mound. The Seyitömer Mound is located $25 \mathrm{~km}$ northwest of the centre of Kütahya province. The Mound is $150 \times 140 \mathrm{~m}$ in size and has a height of $23.5 \mathrm{~m}$. In order to receive 12 million tonnes of coal reserve under the mound, archaeological excavations are being held in the archaeological site. The archaeological excavations were started in 1989. It has been found that the Seyitömer Mound was inhibited by civilizations in the Bronze Age, Achaemenid, Hellenistic and Roman periods (Bilgen [1]). Archaeometrical studies gather different branches of science such as materials science, physics, chemistry and others. Archaeological ceramics may be investigated with different characterization techniques to enlighten production technology of the wares (Papachristodoulou et al. [2], Barone et al. [3]).

Thirty pottery sherds unearthed in the Seyitömer Mound belonging to the Achaemenid period have been investigated. Chemical analysis of samples was performed by wavelength dispersive X-ray fluorescence (WDXRF) and mineralogical/phase composition analysis was performed by X-ray diffraction (XRD) (Vinagre et al. [4], Demirel et al. [5], Kennett et al. [6]) to perform archaeometrical characterization of the artifacts. Scanning electron microscopy (SEM) and energy dispersive spectroscopy (EDS) were used for identification of microstructural and microchemical properties of the samples. Thermogravimetric-differential thermal analysis (TG-DTA) was performed to observe the thermal behaviours of the samples to predict the maximum firing temperatures.
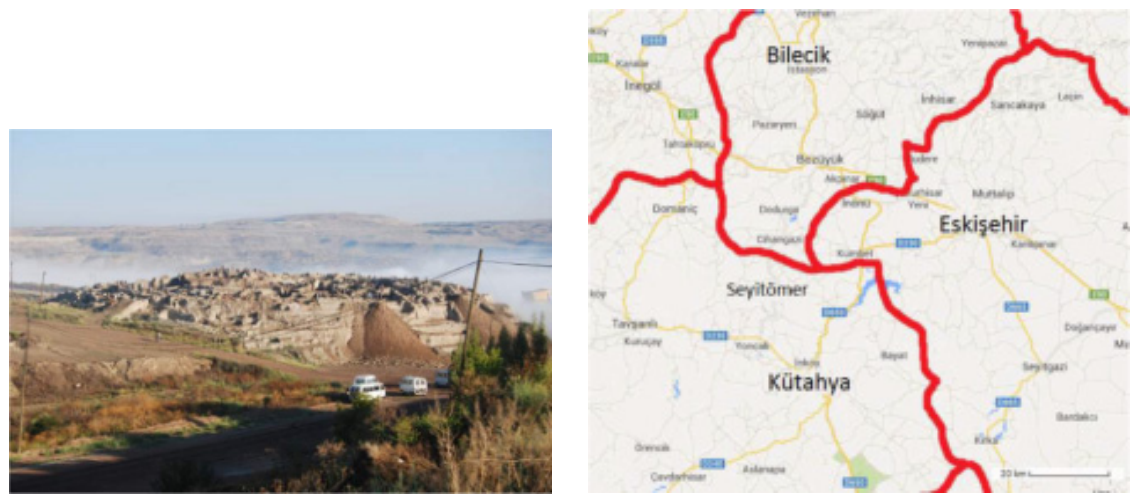

Figure 1: A photograph and a map showing the location of the Seyitömer Mound. 


\section{Materials and methods}

The representative photos of the Achaemenid period samples coded as A10, A11, A14 and A29 are given in Figure 2.

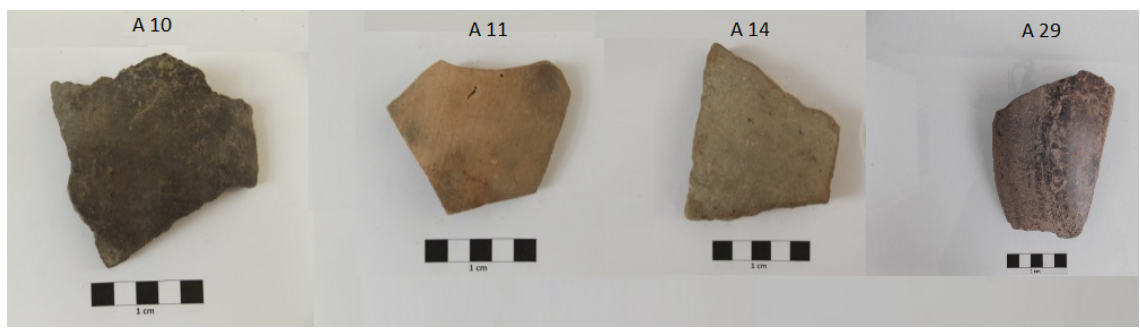

Figure 2: $\quad$ Photos of A10, A11, A14 and A29 coded samples.

Samples were cut by diamond cutting discs and 0.8-1.5 g of samples were obtained. Samples were stored in deionized water to remove impurities for 2 days. Cleaned samples were dried at room temperature. Fine powders were prepared in an agate mortar in order to be analysed by WDXRF and XRD techniques. A Rigaku Miniflex powder diffractometer with $\mathrm{Cu} \mathrm{K} \alpha$ radiation $(\lambda=1.5418 \AA$ ) was used for the mineralogical analysis. XRD patterns were obtained by scanning $5^{\circ}$ to $55^{\circ}$ in $2 \theta$, with a goniometer speed of $2^{\circ} / \mathrm{min}$, operating at $40 \mathrm{kV}$ and $30 \mathrm{~mA}$. The interpretation of mineralogical content of the data was conducted with JADE 7 software by searching and matching the powder diffraction files. A Rigaku ZSX primus wavelength dispersive X-ray fluorescence (WDXRF) instrument was used for chemical analysis of the elements. The measurements were carried out on glass tablets prepared by fluxing powdered samples with $\mathrm{Li}_{2} \mathrm{~B}_{4} \mathrm{O}_{7}$ in 1:10 weigh ratio. The calculation of the semi-quantitative results was conducted with ZSX software. The results were given as oxides. The microstructural and microchemical aspects of the representative potsherds were investigated using FEI Nova Nano 650 SEM instrument which also includes an EDS detector. Setaram Labsys Evo instrument was used for TG-DTA analysis. A heating rate of $10^{\circ} \mathrm{C} / \mathrm{min}$ was performed in oxidative atmosphere from room temperature to $1200^{\circ} \mathrm{C}$.

\section{Results and discussions}

\subsection{Chemical analysis result and discussion}

Instead of giving all the results of the study, chemical analysis results belonging to A10, A11, A14 and A29 which are calcium poor and rich and representing chemical analysis of ceramic groups were given in Table 1.

As seen from the results, the maximum percentage of $\mathrm{CaO}$ belongs to the A11 coded sample, the minimum percentage belongs to the A29 coded sample. Considering the total of alkaline and alkaline-earth oxides, A11 have the maximum quantity. 
610 Sustainable Development, Vol. 1

Table 1: Chemical analysis results of A10, A11, A14 and A29. The term of "n.d." indicates not detected or under the limits of detection by WDXRF technique performed.

\begin{tabular}{|c|c|c|c|c|}
\hline \multirow[b]{2}{*}{ Oxide } & \multicolumn{2}{|c|}{ Calcium Rich } & \multicolumn{2}{|c|}{ Calcium Poor } \\
\hline & A11 & A14 & $\mathbf{A 1 0}$ & A29 \\
\hline $\mathrm{Na}_{2} \mathrm{O}$ & 0.4033 & 0.4169 & 2.117 & 0.586 \\
\hline MgO & 3.0006 & 5.9993 & 2.2023 & 1.3813 \\
\hline $\mathrm{Al}_{2} \mathrm{O}_{3}$ & 15.5556 & 12.1807 & 15.6316 & 22.0702 \\
\hline $\mathrm{SiO}_{2}$ & 48.3133 & 56.5772 & 67.4659 & 59.8809 \\
\hline $\mathbf{P}_{2} \mathbf{O}_{5}$ & 0.2114 & 0.1511 & 0.2873 & 0.3258 \\
\hline $\mathrm{SO}_{3}$ & 0.0741 & 0.0399 & 0.0568 & 0.238 \\
\hline $\mathrm{As}_{2} \mathrm{O}_{3}$ & 0.0306 & n.d. & 0.0128 & 0.0158 \\
\hline $\mathrm{K}_{2} \mathrm{O}$ & 2.2499 & 2.785 & 4.1811 & 4.9322 \\
\hline $\mathrm{CaO}$ & 19.9717 & 12.4227 & 1.5857 & 1.5585 \\
\hline $\mathrm{TiO}_{2}$ & 1.1477 & 0.7191 & 0.6752 & 0.8538 \\
\hline $\mathrm{TeO}_{2}$ & n.d. & n.d. & n.d. & n.d. \\
\hline $\mathrm{Cr}_{2} \mathrm{O}_{3}$ & 0.1035 & 0.2366 & 0.0851 & 0.1088 \\
\hline MnO & 0.1903 & 0.1245 & 0.0506 & 0.1427 \\
\hline $\mathrm{Fe}_{2} \mathrm{O}_{3}$ & 8.6427 & 8.192 & 5.2697 & 7.7677 \\
\hline $\mathrm{Co}_{2} \mathrm{O}_{3}$ & n.d. & 0.0104 & n.d. & n.d. \\
\hline $\mathrm{NiO}$ & 0.0327 & 0.0876 & 0.0275 & 0.0234 \\
\hline $\mathrm{CuO}$ & 0.0159 & n.d. & n.d. & 0.0205 \\
\hline $\mathrm{ZnO}$ & 0.0182 & 0.0212 & 0.0112 & 0.0307 \\
\hline $\mathbf{R} \mathbf{b}_{2} \mathbf{O}$ & n.d. & n.d. & 0.0351 & n.d. \\
\hline SrO & 0.0145 & 0.0175 & 0.0183 & 0.0129 \\
\hline $\mathrm{ZrO}_{2}$ & 0.024 & 0.0184 & 0.0307 & 0.0507 \\
\hline $\mathrm{BaO}$ & n.d. & n.d. & 0.256 & n.d. \\
\hline $\mathrm{SnO}_{2}$ & n.d. & n.d. & n.d. & n.d. \\
\hline $\mathrm{Nb}_{2} \mathrm{O}_{5}$ & n.d. & n.d. & n.d. & n.d. \\
\hline $\mathrm{Ag}_{2} \mathrm{O}$ & n.d. & n.d. & n.d. & n.d. \\
\hline PbO & n.d. & n.d. & n.d. & n.d. \\
\hline $\mathrm{Cl}$ & n.d. & n.d. & n.d. & n.d. \\
\hline $\mathrm{ThO}_{2}$ & n.d. & n.d. & n.d. & n.d. \\
\hline $\mathrm{V}_{2} \mathrm{O}_{5}$ & n.d. & n.d. & n.d. & n.d. \\
\hline
\end{tabular}




\subsection{Mineralogical/phase analysis results and discussion}

Determined minerals/phases for the samples are: Quartz $\left(\mathrm{SiO}_{2}\right)$, Plagioclase, Illite $\left(\left(\mathrm{K}, \mathrm{H}_{3} \mathrm{O}\right) \mathrm{Al}_{2} \mathrm{Si}_{3} \mathrm{AlO}_{10}(\mathrm{OH})_{2}\right)$, Microcline $\left(\mathrm{KAlSi}_{3} \mathrm{O}_{8}\right)$, Calcite $\left(\mathrm{CaCO}_{3}\right)$, Muscovite $\left(\mathrm{KAl}_{2}\left(\mathrm{Si}_{3} \mathrm{Al}\right) \mathrm{O}_{10}(\mathrm{OH}, \mathrm{F})_{2}\right)$, Gehlenite $\left(\mathrm{Ca}_{2} \mathrm{Al}_{2} \mathrm{SiO}_{7}\right)$, Dolomite $\left(\mathrm{CaMg}\left(\mathrm{CO}_{3}\right)_{2}\right)$, Hematite $\left(\mathrm{Fe}_{2} \mathrm{O}_{3}\right)$, Maghemit $\left(\mathrm{Fe}_{2} \mathrm{O}_{3}\right)$, Kaliophilite $\left(\mathrm{KAlSiO}_{4}\right)$, Wollastonite $\left(\mathrm{CaSiO}_{3}\right)$, Diopside $\left(\mathrm{Ca}(\mathrm{Mg}, \mathrm{Al})(\mathrm{Si}, \mathrm{Al})_{2} \mathrm{O}_{6}\right) . \mathrm{XRD}$ analysis results of $\mathrm{A} 10, \mathrm{~A} 11$, A14 and A29 coded samples and raw materials of clays are given in Table 2.

Table 2: $\quad$ XRD analysis results of A10, A11, A14 and A29 coded samples and raw materials of clays.

\begin{tabular}{|c|c|}
\hline Sample Code & Minerals/Phases \\
\hline A 10 & $\begin{array}{c}\text { Quartz, Plagioclase, Muscovite, Microcline, Wollastonite, } \\
\text { Gehlenite, Maghemite. }\end{array}$ \\
\hline A11 & $\begin{array}{c}\text { Quartz, Plagioclase, Kaliophilite, Calcite, Dolomite, } \\
\text { Hematite, Maghemite. }\end{array}$ \\
\hline A14 & $\begin{array}{c}\text { Quartz, Plagioclase, Muscovite, Calcite, Dolomite, } \\
\text { Maghemite. }\end{array}$ \\
\hline A29 & $\begin{array}{c}\text { Quartz, Plagioclase, Muscovite, Microcline, Kaliophilite, } \\
\text { Diopside, Gehlenite, Maghemite. }\end{array}$ \\
\hline SNLKKY & $\begin{array}{c}\text { Quartz, Plagioclase, Illite/Muscovite, Montmorillonite, } \\
\text { Kaolinite, Calcite, Dolomite. }\end{array}$ \\
\hline AYVALIB & $\begin{array}{l}\text { Quartz, Plagioclase, Illite/Muscovite, Talc, Kaolinite, } \\
\text { Kaliophilite, Calcite, Dolomite. }\end{array}$ \\
\hline CKOY2B & $\begin{array}{l}\text { Quartz, Plagioclase, Illite/Muscovite, } \\
\text { Kaolinite/Montmorillonite, Calcite. }\end{array}$ \\
\hline IK3A & $\begin{array}{l}\text { Quartz, Plagioclase, Illite/Muscovite, Talc, Montmorillonite, } \\
\text { Kaolinite, Calcite. }\end{array}$ \\
\hline SO1K & $\begin{array}{c}\text { Quartz, Plagioclase, Illite/Muscovite, Montmorillonite, } \\
\text { Kaolinite, Calcite, Dolomite. }\end{array}$ \\
\hline
\end{tabular}

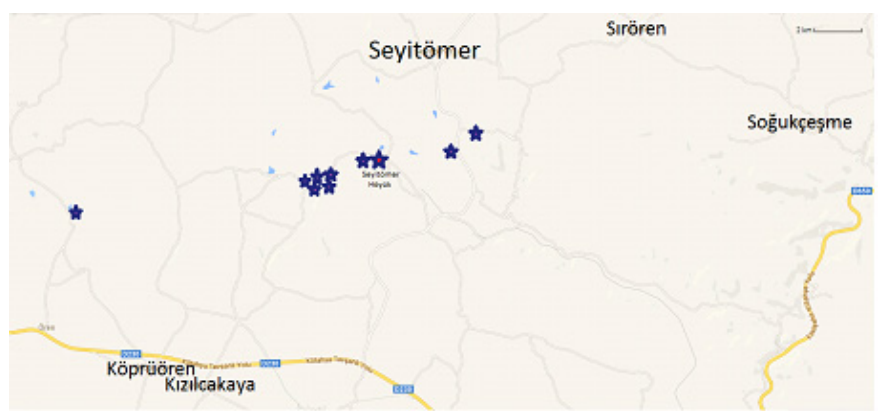

Figure 3: A map shows the raw materials (clays) collected around the Seyitömer Mound. 
XRD results of the raw materials (clays) collected around the Seyitömer Mound are also given in Table 2. They were coded as SNLKKY, AYVALIB, CKOY2B, IK3A and SO1K.

Quartz is a mineral with high heat of melting. For this reason, quartz mineral exists in all samples. Quartz and feldspars can persist up to $1000^{\circ} \mathrm{C}$ (İssi et al. [7]). Gehlenite begins to form at $800^{\circ} \mathrm{C}$ and disappear at $900^{\circ} \mathrm{C}$ (Veniale [8]). Illite/muscovite or mica structure breaks down in the range of $900-1000^{\circ} \mathrm{C}$ (Grimshaw [9]). Gehlenite may be formed at $850^{\circ} \mathrm{C}$ with the reaction of $\mathrm{CaO}$ and illite structure, diopside may be generated from dolomite and silica reactions at 800-900 ${ }^{\circ} \mathrm{C}$ (Cultrone et al. [10]).

A10, A14 and A29 coded samples contain illite/muscovite minerals. They could have been fired under $1000^{\circ} \mathrm{C}$. A10 and A29 coded samples contains gehlenite mineral. A10 and A29 coded samples possibly sintered around $800^{\circ} \mathrm{C}$. Calcite and dolomite decomposition begin under $700^{\circ} \mathrm{C}$ and is completed up to $850^{\circ} \mathrm{C}$ (Lopez-Arce et al. [11]). Therefore, A11 and A14 coded samples could have been fired in the lowest temperature. Another suggestion from the results is related with the atmosphere of firing. Hematite indicates oxidative firing (Damjanovic et al. [12]). However, existence of maghemite phase on XRD pattern cannot be excluded but, reductive atmosphere should have been provided for firing (Legodi and de Waala [13]). A29 coded sample contains diopside. Presence of diopside indicates that the original raw material had dolomite or another type of mineral which contain magnesium. In the case of dolomite presence, diopside is originated through the following reaction beginning at $900^{\circ} \mathrm{C}$. It may be suggested that A29 coded sample firing temperature is around $900^{\circ} \mathrm{C}$ (Fort et al. [14]).

\subsection{SEM analysis results and discussion}

SEM images of $\mathrm{Ca}$ rich and poor samples are given in Figure 4.

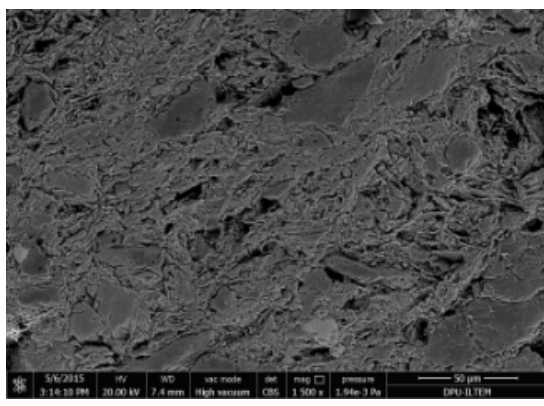

(a)

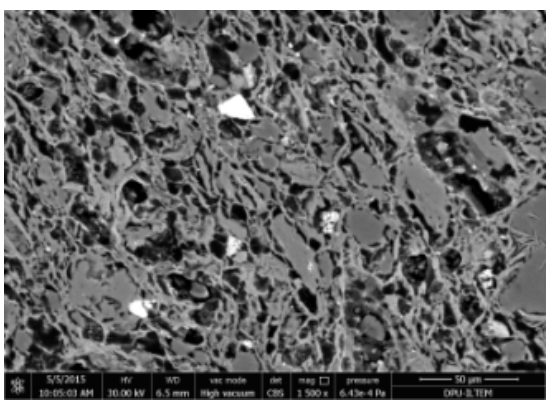

(b)

Figure 4: $\quad$ SEM images of Ca rich A11 coded sample (a) and Ca poor A29 coded sample (b).

Some changes with increasing temperature in clay based ceramics can be described as (i) interactions between clay matrix and grains, (ii) shape changes of grains, (iii) increase of the aggregation rate within the clay matrix with the 
formation of secondary porosity, and (iv) formation of intergranular bridges. These changes become more evident in calcareous clays than the siliceous materials including clays (Riccardi et al. [15]). Since some of the samples contain high amounts of calcium, SEM images exhibited predominantly arrangements of calcium rich new mineral formations in the microstructure of the samples (Figure 4(a)). Quartz is one of the primary components of clay based ceramics with high melting temperature. It is considered that quartz is relatively insoluble below $1250^{\circ} \mathrm{C}$, dissolution of quartz forms silica-rich amorphous solution rims around quartz grains (Iqbal and Lee [16]). Quartz grain dissolution into vitrified clay matrix of the sample may easily be distinguished by the atomic contrast difference in BSE images. Feldspar is believed to melt around $1100^{\circ} \mathrm{C}$ in the contact zone between feldspar crystals and clay relicts and potash matrix require high temperature around $1200^{\circ} \mathrm{C}$.

\subsection{Thermogravimetric-differential thermal analysis TG-DTA results and discussion}

TG-DTA is the preferred method in characterization of potteries. This technique allows the examination of changes occurred due to the decomposition, transformation and formation reactions during a controlled heating process (Drebushchak et al. [17]). Samples were heated from room temperature to $1200^{\circ} \mathrm{C}$ with a heating rate of $10^{\circ} \mathrm{C} / \mathrm{min}$ in order to expose the enthalpy changes (plotted by DTA curves with endothermic and exothermic effects) and weight loss/gain (plotted by TG curves).

The endothermic effect from room temperature to $200^{\circ} \mathrm{C}$ is due to the release of hygroscopic water (Maritan et al. [18]). At higher temperatures of $200-300^{\circ} \mathrm{C}$ the endothermic effect depicts the removal of the chemically bound water, but it may not met in the present study (Paama et al. [19]). Depending on the area of the peaks observed in the range of $200-650^{\circ} \mathrm{C}$, the exothermic effect identified within these temperatures was attributed to the combustion of organic materials, not completely burnt during firing in reducing condition and transformed into carbonaceous particles which are thought to be deliberately added into the ceramic paste to increase its plasticity or were contained in the clay utilized in the manufacture (Palanivel and Rajesh Kumar [20]). The endothermic effects observed at $700-875^{\circ} \mathrm{C}$ indicated the decarbonation reactions of mainly calcite and dolomite (Meyvel et al. [21]).

TG-DTA results of selected samples are given in Figures 5 and 6.

Mass loss peak in A10 coded sample is around 5.5\%. As it can be seen from the Figure 5, mass change is methodical up to $400^{\circ} \mathrm{C}$. Considering TG analysis with XRD results weight loss originates from the reactions of unbound or adsorbed water or burning of organic substance. DTA analysis shows exothermic reaction in $435^{\circ} \mathrm{C}$. This may suggest of organic based materials burning. Endothermic reaction in $575^{\circ} \mathrm{C}$ is also due to the crystal water decomposition in A10 coded sample. Mass loss of A11 coded sample is around 7\%. According to TG analysis mass change is methodical up to $640^{\circ} \mathrm{C}$ and considering with $\mathrm{XRD}$ results, 


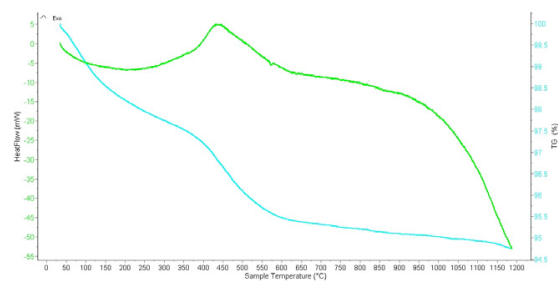

(a)

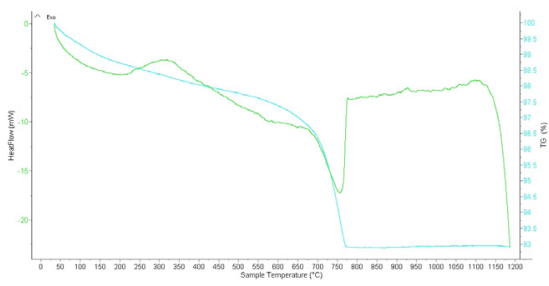

(b)

Figure 5: TG-DTA curve of the sample of A10 (a) \& A11 (b).

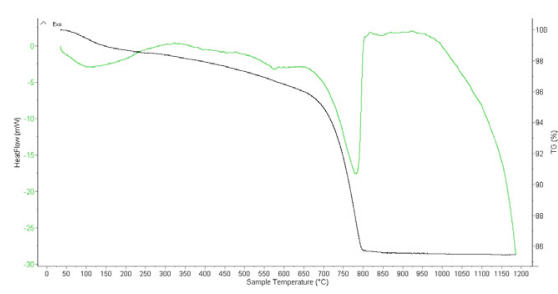

(a)

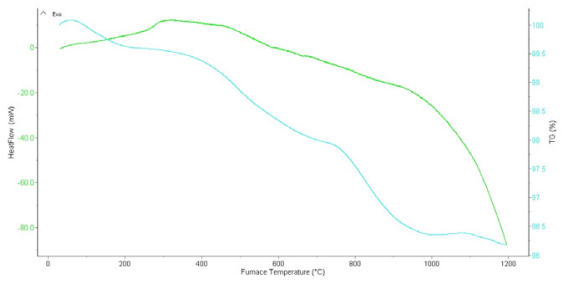

(b)

Figure 6: TG-DTA curve of the sample of A14 (a) and A29 (b).

conclusions are similar with A10 coded sample. DTA analysis of A11 coded sample shows a reaction in $725^{\circ} \mathrm{C}$. This may suggest calcite decomposition. Mass loss of A14 coded sample is around $14 \%$. Mass change is methodical up to $675^{\circ} \mathrm{C}$. DTA analysis of A14 coded sample shows endothermic reaction in $575^{\circ} \mathrm{C}$. This may be crystal water decomposition. Endothermic reaction at $780^{\circ} \mathrm{C}$ also because of calcite decomposition. Mass loss of A29 coded sample is around 4\%. As seen in Figure 6 mass change is methodical up to $775^{\circ} \mathrm{C}$. DTA analysis shows there are no materials such as clays or silicates to make any weight loss or endo-exothermic reactions.

\section{Conclusions}

From WDXRF, XRD, SEM and TG-DTA analysis results obtained, the Achaemenid period ceramics unearthed in the Seyitömer Mound have been produced from clay deposits containing illitic type minerals with rich in iron and calcium rich and poor accessory minerals. To compare with regional geological formations and raw material sources, it may be suggested that local raw material source is enough to produce such kind of ceramic wares during the Achaemenid period. According to phases/minerals in Achaemenid period samples firing temperatures are between $600^{\circ} \mathrm{C}$ and $900^{\circ} \mathrm{C}$. 


\section{Acknowledgement}

This study is a part of ongoing project titled "Archaeometrical Characterization of Ceramic Findings Belonging to Achaemenid, Hellenistic and Roman Periods from Seyitömer Mound (Kütahya)" with the project number of 113K096. The Scientific and Technological Research Council of Turkey (TÜBİTAK) is acknowledged.

\section{References}

[1] Bilgen A.N., Seyitömer Höyük Kazısı Ön Raporu. P.1 Kütahya, 2011 (in Turkish).

[2] Papachristodoulou C., Oikonomou A., Ioaniddes K. \& Gravani K., A Study of Ancient Pottery by Means of X-Ray Fluorescence Spectroscopy, Multivariate Statistics and Mineralogical Analysis. Analytica Chimica Acta., 573, pp. 347-353, 2006.

[3] Barone G., Crupi V., Galli S., Majolino D., Migliardo P. \& Venuti V., Spectroscopic İnvestigation of Greek Ceramic Artefacts. Journal of Molecular Structure, 651, pp. 449-458, 2003.

[4] Vinagre U.M., Latini R.M., Bellido A.V.B., Buarque A. \& Borges A.M., Ancient Ceramics Analysis by Neutron Activation in Association with Multivare Methods, Brazilian Journal of Physics, 35, pp. 779-781, 2005.

[5] Demirel M., Sevin F.B., Say R. \& Yazan Y., Propranolol HCl Imprinted Polymeric Microspheres: Development, Characterization and Dissolution. FABAD J. Pharm. Sci., 32, pp. 147-157, Ankara, 2007.

[6] Kennett D.J., Sakai S., Neff H., Gossett R. \& Larson D.O., Compositional Characterisation of Prehistoric Ceramics: A New Approach. Journal of Archaeological Science, 29, pp. 443-455, 2002.

[7] İssi A., Kara A. \& Alp A.O., An Investigation of Hellenistic Period Pottery Production Technology from Harabezikan/Turkey. Ceramics International, 37, pp. 2575-2582, Eskişehir, 2011.

[8] Veniale F., Modern techniques of analysis applied to ancient ceramics. In: Advanced workshop on analytical methodologies for the investigation of damaged Stones, Pavia, (Italy), 1990.

[9] Grimshaw R.W., The Chemistry and Physics of Clays. Techbooks, p. 727, India, 1971.

[10] Cultrone G., Navarro C.R., Sebastian E., Cazalla O. \& Torre M.J., Carbonate and Silicate Phase Reactions during Ceramic Firing. Eur. J. Mineral., 13, pp. 621-634, Stuttgart (Germany), 2001.

[11] López-Arce P., Garcia-Guinea J., Gracia M. \& Obis J., Bricks in historical buildings of Toledo City: characterisation and restoration. Mater. Charact., 50, pp. 59-68, 2003.

[12] Damjanovic L., Antunovic I.H., Mioc U.B., Bikic V., Milanovic D. \& Evans I.R., Archaeometric study of medieval pottery excavated at Stari (Old) Ras Serbia. J. Archaeol. Sci., 38, pp. 818-828, 2011. 
[13] Legodi M.A. \& de Waala M.A., The preparation of magnetite, goethite, hematite and maghemite of pigment quality from mill scale iron waste. Department of Chemistry, University of Pretoria, v.74, i.1, pp. 161-168, Pretoria (South Africa), 2007.

[14] Fort R., Alvarez de Buergo M., Gomez-Heras M. \& Vazquez-Calvo C., Heritage, Weathering and Conservation. Taylor \& Francis Group, Vol. 2, p. 940, London, 2006.

[15] Riccardi M.P., Messiga B. \& Duminuco P., An approach to the dynamics of clay firing, Appl. Clay Sci., 15, pp. 393-409, 1999.

[16] Iqbal Y. \& Lee W.E., Microstructural evolution in triaxial porcelain, J. Am. Ceram. Soc., 83, pp. 3121-3127, 2000.

[17] Drebushchak V.A., Mylnikova L.N., Drebushchak T.N. \& Boldyrev V.V., The investigations of ancient pottery, J. Therm. Anal. Calorim., 82, pp. 6176262005.

[18] Maritan L., Nodari L., Mazzoli C., Milano A. \& Russo U., Influence of firing conditions on ceramic products: experimental study on clay rich in organic matter. Appl. Clay Sci., pp. 311-315, 2006.

[19] Paama L., Pitkanen I. \& Peramaki P., Analysis of archeological samples and local clays using ICP-AES, TGDTG and FTIR techniques. Talanta, 51, pp. 349-357, 2000.

[20] Palanivel R. \& Rajesh Kumar U., Thermal and spectroscopic analysis of ancient potteries. Rom. J. Phys., 56, pp. 195-208, 2011.

[21] Meyvel S., Sathya P. \& Velraj G., Thermal characterization of archaeological potsherds recently excavated in Nedunkur, Tamilnadu, India, Cerâmica, 58 pp. 338-341, 2012. 